\title{
液状マルチ資材の散布がコマツナの生育，収量ならびに地温に及ぼす影響
}

\author{
佐藤達雄 ${ }^{1 *}$ ・塩原由紀江 ${ }^{1} \cdot$ 大森明文 $^{1} \cdot$ 芳野未央子 $^{1} \cdot$ 久芳慶子 ${ }^{1} \cdot$ \\ 高田圭太 ${ }^{1} \cdot$ 池田由紀 ${ }^{1} \cdot$ 元木 悟 $^{2} \cdot$ 小倉秀 ${ }^{3} \cdot$ 工藤光夫 $^{3}$ \\ 1 茨城大学農学部附属>ィールドサイエンス教育研究センター 300-0331 茨城県稲敷郡阿見町阿見 \\ 2 長野県野菜花き試験場北信支場 381-1211 長野県長野市松代町大室 \\ ${ }^{3}$ 株式会社テルナイト 151-0072 東京都渋谷区幡ヶ谷
}

\section{The Effects of Liquid-coating Mulch Spray on Growth, Yield and Undersoil Temperature in Komatsuna Greens (Brassica rapa L.)}

\author{
Tatsuo Sato ${ }^{1}$, Yukie Shiobara ${ }^{1}$, Akifumi Omori ${ }^{1}$, Mioko Yoshino ${ }^{1}$, Keiko Kuba ${ }^{1}$, \\ Keita Takada ${ }^{1}$, Yuki Ikeda ${ }^{1}$, Satoru Motoki ${ }^{2}$, Shuichi Ogura ${ }^{3}$ and Mitsuo Kudo ${ }^{3}$ \\ ${ }^{I}$ Field Science Center, Collage of Agriculture, Ibaraki University, Ami, Inashiki, Ibaraki 300-0331 \\ ${ }^{2}$ Nagano Vegetable and Ornamental Crops Experiment Station, Hokushin Branch, Omuro, Matsushiro, Nagano 381-1211 \\ ${ }^{3}$ Telnite CO., LTD., Hatagaya, Shibuya, Tokyo 151-0072
}

\begin{abstract}
This experiment was intended to examine the effects of a black liquid-coating mulch on the growth and yield of Komatsuna greens. Four treatments $\left(1,0.5,0.25 \mathrm{~L} \cdot \mathrm{m}^{-2}\right)$ of spray amount were tested in combination with seeding date (Sep. $21^{\text {st }}$, Oct. $5^{\text {th }}$, Oct. $20^{\text {th }}$ in an open field and the Jan. $22^{\text {nd }}$ in a plastic film house). As a result, we found this liquid-coating mulch increased yields of Komatsuna greens, unrelated to the spray amount. Generally, the daily highest soil temperature $(-5 \mathrm{~cm})$ under the mulching exceeded the control in every treatment however the daily lowest temperature were less than control except in the case of seeding at Sep. $21^{\text {st }}$. These phenomena were remarkable in the early stage of growing and the differences in temperature between the control and mulch treatments were reduced during the growth. There was no significant difference in the hourlyintegrated temperature during the first 10 days between the 4 treatments on same seeding date. These findings suggest that the expansion of the daily soil temperature range contributed the increased yields of Komatsuna greens.
\end{abstract}

Key Words : daily temperature range, heat radiation, cumulative temperature, maximum undersoil temperature, minimum undersoil temperature

キーワード : 熱放散, 日較差，最高地温，最低地温，積算温度

\begin{abstract}
緒言
現在, わが国ではポリエチレン製のマルチフィルム（ポ リマルチ）が広く普及している（小寺，2003）。ポリマルチ は，使用目的に合わせて様々な製品が開発され多くの作物 で利用されているが, 軟弱野菜では栽植密度や作業上の理 由から普及していない，そこで，軟弱野菜に打けるマルチ ングの効果を得るため, 過去にいくつかほかの方法が検討 されてきた. 富田ら（1997）は, 夏まきホウレンソウの地 温上昇抑制のため, パーライトや卵殼の散布が地表面温度 上昇抑制に有効であることを明らかにした．中島ら（2003） は植え孔を開けた紙マルチとシードテープを併用すること によりコマッナ, カブ, ハッカダイコン, ニンジンの生育
\end{abstract}

2008 年 5 月 11 日 受付. 2008 年 12 月 8 日 受理.

* Corresponding author. E-mail: sugar@mx.ibaraki.ac.jp
促進と除草に有効であることを明らかにした，しかし，こ れらの資材はコストや材料調達, 散布作業の簡便性の面か ら未だ実用に至っていない，それらの問題を解決するため 液状資材散布によるマルチング方法が中川・金澤（2001） により考案され, 近年, 生分解性の高分子エマルジョン, 黒色顔料 (カーボンブラック), フミン酸塩類を混合した資 材が試作されている（工藤ら，2007; 中川ら，2004）。この 資材は大量生産が可能であり，霧吹きや動力噴霧器で容易 に散布でき，微生物分解され廃棄物を発生しないといら特 徵を具備する. 元木ら（2007）は, 軟弱野菜同様ポリマル チの使用が困難なアスパラガスについて使用を検討し，地 温上昇による初期収量の顕著な増加を報告し，実用的見地 から有用性を示した。 そこで, 本研究ではコマッナの播種 直後に液状マルチ資材を散布し, 生育, 収量ならびに地温 の経過を観察することによって，秋冬季に打ける本資材の 特性を明らかにするとともにコマッナの生育, 収量に及ぼ 
す影響を評価した.

\section{材料および方法}

\section{1. 試験区の設定ならびに供試材料}

試験区の設定は, 黒色の液状マルチ資材（商品名「エコ・ サンコート」，株式会社テルナイト） 5 倍希釈液を用い，処 理量を $1 \mathrm{~L} \cdot \mathrm{m}^{-2}$ (倍量) 区, $0.5 \mathrm{~L} \cdot \mathrm{m}^{-2}$ (標準量) 区, $0.25 \mathrm{~L} \cdot$ $\mathrm{m}^{-2}$ (半量) 区，無処理区の 4 水準 3 反復，播種日を 2007 年 9 月 21 日，10月 5 日，10 月 20 日打よび 2008 年 1 月 22 日の 4 水準として組久合わせた. 1 区面積は $1.2 \mathrm{~m}^{2}$ とした. コマッナの供試品種としては 'タすぎ’（(株）サカタのタ ネ）を用いた。

\section{2. 耕種概要および調査項目}

围場は茨城大学農学部附属フィールドサイエンス教育研 究センタ一内試験圃場（褐色火山性土䁃, 土性 CL) を使 用した. 1 年生雑草防除のため, 播種 10 日以前にダゾメッ 卜粉粒剂 $2 \mathrm{~kg} ・ \mathrm{a}^{-1}$ を処理した． 9 月 21 日，10月 5 日拈よ び 10 月 20 日播種は露地で， 1 月 22 日播種は最低温度を $8^{\circ} \mathrm{C}$ にしたプラスチックフィルムハウス (間口 $5.4 \mathrm{~m} \times$ 奥行 き $18 \mathrm{~m}, \mathrm{PO}$ フィルム展張) で栽培を行った. 施肥は $\mathrm{N}: \mathrm{P}_{2} \mathrm{O}_{5}$ : $\mathrm{K}_{2} \mathrm{O}=15 \mathrm{~g} \cdot \mathrm{m}^{-2}: 15 \mathrm{~g} \cdot \mathrm{m}^{-2}: 15 \mathrm{~g} \cdot \mathrm{m}^{-2}$ を全面全層混和とし た. 栽植様式は東西方向にベッドを造成し, ベッド幅 $100 \mathrm{~cm}$ （南北に条間 $12 \mathrm{~cm} 10$ 条 $\times$ 株間 $5 \mathrm{~cm}$ ) +通路 $40 \mathrm{~cm}$ とし, 1 か所 $2 \sim 3$ 粒まきで発芽後間引き， 1 か所 2 株とした. 液 状マルチ資材は，播種当日に霧吹きでベッド全面に散布し た. 防除は 9 月 21 日，10月 5 日播種でシペルメトリン乳 剤を 1 回散布した。 かん水は行わなかった。

収穫は無処理区の最大葉長が概ね2 $20 \mathrm{~cm}$ 越えた日とし， 1 区当たり 5 条 $\times 10$ 株 $\left(0.15 \mathrm{~m}^{2} ， 50\right.$ 個体／区）を拔き取り 重量を測定するとともに生育中庸な 10 株を用いて最大葉 長，葉数，最大葉幅敃よび最大葉柄長を調査した。また， すべての試験区 $(4$ 処理 $\times 3$ 反復 $\times 4$ 播種期 $=48$ 点 $)$ の条 間に地下 $5 \mathrm{~cm}$ にデータロガー「サーモクロン $\mathrm{G} 」($ 株式会 社 KN ラボラトリーズ）を埋設し，生育期間中の毎正時温 度を記録して 3 反復の平均值を求め各処理の代表値とした. 9 月 21 日， 10 月 20 日播種ではテンションメーターで 1 反 復の夕地下 $20 \mathrm{~cm}$ の土壤水分を測定した. 9 月 21 日，10月 5 日，10月 20 日拈よび 1 月 22 日播種の收穫調査はそれぞ れ10月13日, 10 月 31 日, 12 月 6 日拈よび2月 22 日に行った.

\section{結果および考察}

10 月 5 日播種では液状マルチ資材散布直後に驟雨があ り, 目視で試験区の判別が困難な程度に液状マルチ資材 が流亡したため，翌日，再散布を行った。 その他は特に問 題なく経過した，発芽率，発芽々ろいの良否については各 区と夕差が認められなかった。 9 月 21 日播種ならびに 10 月 20 日播種の試験期間に打梳主水分は $\mathrm{pF} 1.5 \sim 1.7$ の 間で安定していた. 平均気温は試験を開始した 9 月 21 日〜 11 月中旬まで急激に，それ以降は緩やかに低下した（第 1
図).液状マルチ資材の処理量がコマッナの生育に及ぼす影 響について二元配置分散分析を行ったところ，各調査項目 について交互作用はなかった，異なる播種日の影響は最大 葉長，葉数，最大葉柄長拈よび収量に捺いて危険率 1\%で 有意な差が認められた（第 1 表）。この差異は生育時期の草 姿の違いによる環境条件の違いに起因寸るものと考兄られ た．収量については液状マルチ資材散布量の影響は収量に ついての久危険率 5\%で有意な差が認められたが，最大葉 長，葉数，最大葉幅拈よび最大葉柄長においては有意な差 がみられなかった．各調査項目について，交互作用ならび に各播種日内での散布量間に有意な差は認められなかっ た. 次に散布量が収量に拈よぼす影響について Tukeyの多 重比較を行ったところ, $1 \mathrm{~L} \cdot \mathrm{m}^{-2}$ 区, $0.5 \mathrm{~L} ・ \mathrm{~m}^{-2}$ 区， $0.25 \mathrm{~L} ・$ $\mathrm{m}^{-2}$ 区と無処理区の間で有意な差が認められ，無処理区の 収量が低かった。このことから，液状マルチ散布で葉の サイズや数には有意差がなかったが，1葉重量が増加した ことからコマッナの増收に結びついたものと判断された (第 1 表)．次に，液状マルチの標準量処理である $0.5 \mathrm{~L} ・ \mathrm{~m}^{-2}$ 区と無処理区の間に抢㵊高地温の差の推移を第 2 図に 示した. 9 月 21 日播種では，播種翌日は無処理区に対し $0.5 \mathrm{~L} \cdot \mathrm{m}^{-2}$ 区の最高地温が $0.8^{\circ} \mathrm{C}$ 高かったが，温度差は次 第に小さくなり，生育中期以降は $0.2 \sim 0.3^{\circ} \mathrm{C}$ 低く経過し た. 10 月 5 日播種でも同様に播種翌日は $1.2^{\circ} \mathrm{C}$ 高かった が，温度差は次第に小さくなり，生育中期以降は $0.2 \sim$ $1.0^{\circ} \mathrm{C}$ 低く経過した. 10 月 19 日播種では, 播種翌日は $1.7^{\circ} \mathrm{C}$ 高く, 最高 $3^{\circ} \mathrm{C}$ 以上の差がっく日もあった．温度差は次第 に小さくなり, 収穫期には $0.3^{\circ} \mathrm{C}$ 高かった。 これに対して 1 月 22 日播種では $-0.2 \sim 1.3^{\circ} \mathrm{C}$ の間で変動が大きかった が，概衫無処理区より高温に推移し，収穫 10 日前より温度 差が小さくなった．生育の進行に伴ら温度差の縮小は，コ マッナ茎葉部の発達による地表面の被覆が原因と考兄られ た. 門田（1972）は，コマッナと同種に属するカブ，八ク サイの根ならびに地上部の伸長に及洔す地温の影響を調査

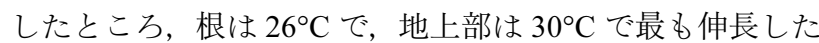
と報告していることから，この時期の最高地温の上昇は初 期生育を促進すると考兄られるが，コマッナの生育が進み 土壤に到達する日射量が低下寸ると地温上昇効果は低下寸 ることが示唆された（第2図）。

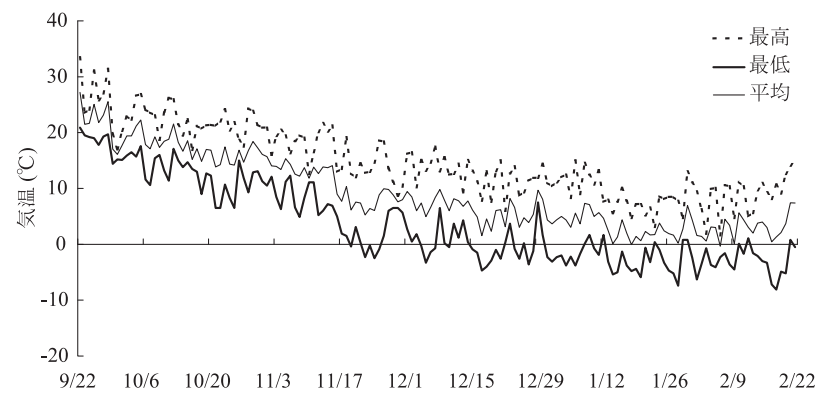

第 1 図 栽培期間中の気温の推移 
第 1 表 液状マルチの処理量がコマツナの生育に及ぼす影響

\begin{tabular}{|c|c|c|c|c|c|c|}
\hline 播種日（月日） & 散布量 $\left(\mathrm{L} \cdot \mathrm{m}^{-2}\right)$ & 最大葉長 $(\mathrm{cm})$ & 葉数（枚） & "最大葉幅 $(\mathrm{cm})$ & "最大葉柄長（cm） & 收量 $\left(\mathrm{g} \cdot \mathrm{m}^{-2}\right)$ \\
\hline \multirow{4}{*}{9 月 21 日 } & $\begin{array}{l}\text { 無処理 } \\
\end{array}$ & 26.2 & 4.13 & 8.43 & 14.6 & 1,967 \\
\hline & 0.25 & 25.3 & 4.33 & 8.60 & 13.7 & 1,914 \\
\hline & 0.5 & 27.4 & 4.57 & 8.33 & 15.3 & 2,079 \\
\hline & 1 & 27.4 & 4.17 & 8.32 & 15.5 & 2,157 \\
\hline \multirow{4}{*}{10 月 5 日 } & 無処理 & 24.6 & 4.60 & 8.28 & 14.1 & 1,808 \\
\hline & 0.25 & 25.8 & 4.57 & 8.23 & 15.4 & 2,286 \\
\hline & 0.5 & 26.0 & 4.77 & 8.35 & 14.9 & 2,217 \\
\hline & 1 & 26.0 & 4.23 & 8.07 & 14.5 & 2,275 \\
\hline \multirow{4}{*}{10 月 19 日 } & 無処理 & 21.2 & 3.97 & 7.60 & 11.6 & 1,802 \\
\hline & 0.25 & 23.3 & 4.40 & 8.23 & 12.2 & 2,194 \\
\hline & 0.5 & 23.7 & 4.43 & 8.28 & 12.8 & 2,240 \\
\hline & 1 & 23.4 & 4.53 & 8.22 & 12.5 & 2,351 \\
\hline \multirow{4}{*}{1 月 22 日 } & $\begin{array}{l}\text { 無処理 } \\
\end{array}$ & 22.6 & 5.40 & 8.28 & 11.2 & 3,011 \\
\hline & 0.25 & 23.1 & 5.35 & 8.33 & 11.9 & 3,641 \\
\hline & 0.5 & 23.9 & 5.65 & 8.53 & 12.1 & 3,574 \\
\hline & 1 & 23.9 & 5.65 & 8.95 & 12.2 & 3,716 \\
\hline \multirow{3}{*}{ F-test ${ }^{2}$} & 播種日 & $* *$ & $* *$ & $\mathrm{~ns}$ & $* *$ & $* *$ \\
\hline & 散布量 & ns & ns & ns & ns & $*$ \\
\hline & 交互作用 & ns & ns & ns & ns & ns \\
\hline \multirow{4}{*}{ 多重検定 ${ }^{\mathrm{y}}$} & $\begin{array}{l}\text { 無処理 } \\
\end{array}$ & $23.6^{x}$ & 4.53 & 8.15 & 12.9 & $2,147 b$ \\
\hline & 0.25 & 24.4 & 4.71 & 8.38 & 13.2 & $2,509 \mathrm{a}$ \\
\hline & 0.5 & 25.2 & 4.80 & 8.34 & 13.9 & $2,528 \mathrm{a}$ \\
\hline & 1 & 24.9 & 4.65 & 8.39 & 13.7 & $2,625 \mathrm{a}$ \\
\hline
\end{tabular}

z: *,**は2-way ANOVA によりそれぞれ 5\%，1\%水準で有意差あり．ns：有意差なし

y: アルファベットが異なる場合, Tukeyの多重検定（5\%水準）による有意差あり

x: 4 回の播種日の平均を示す

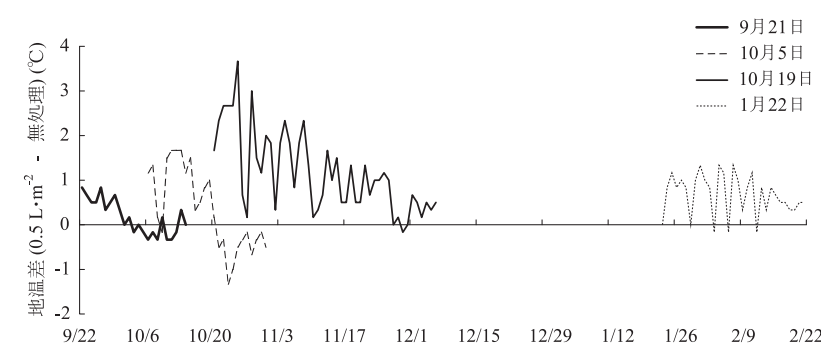

第 2 図 液状マルチ $0.5 \mathrm{~L} \cdot \mathrm{m}^{-2}$ 散布区と無処理区の間の最高 地温の差の推移

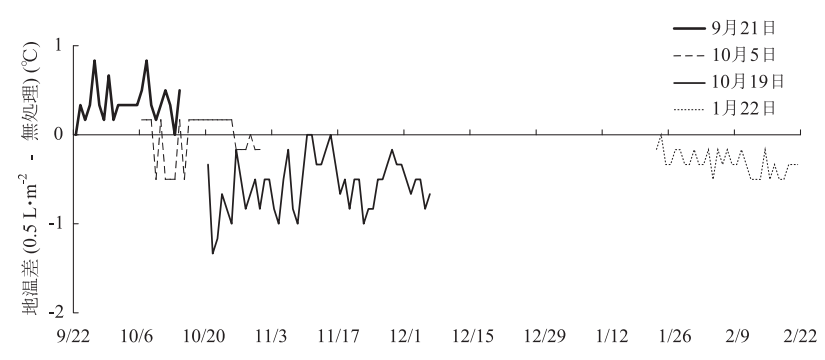

第 3 図 液状マルチ $0.5 \mathrm{~L} ・ \mathrm{~m}^{-2}$ 散布区と無処理区の間の最低 地温の差の推移

第 2 表 液状マルチ $0.5 \mathrm{~L} \cdot \mathrm{m}^{-2}$ 区処理と無処理区間の最低地温の差と気象要因の相関関係

\begin{tabular}{rccccc}
\hline \hline 播種日 & 最低地温 $^{\mathrm{z}}$ & 最低地温 - 最低気温 & 最低気温 & 最高気温 - 最低気温 & 平均風速 \\
\hline 月 21 日 & -0.183 & $0.482^{*}$ & $-0.492^{*}$ & 0.224 & -0.069 \\
10 月 5 日 & $-0.468^{* \mathrm{y}}$ & 0.295 & $-0.509^{* *}$ & 0.303 & -0.063 \\
10 月 19 日 & 0.071 & $-0.547^{* *}$ & $0.307^{*}$ & -0.541 & -0.003 \\
1 月 22 日 & -0.244 & -0.201 & 0.129 & -0.093 & -0.095 \\
\hline
\end{tabular}

z: 無処理区における日最低地温

y: **は $1 \%$ 水準で, *は 5\%水準でそれぞれ正，負の相関関係があることを示す

最低地温は，9月 21 日播種では無処理区に対し $0.5 \mathrm{~L} ・$ $\mathrm{m}^{-2}$ 区は $0 \sim 0.8^{\circ} \mathrm{C}$ 高く推移したが, 最高地温のように 生育進行に温度差の縮小寸る傾向は見られなかった. 10 月 5 日播種では, $-0.5 \sim 0.2{ }^{\circ} \mathrm{C}$ の範囲で推移した. 10 月 19 日 播種では, $-1.3 \sim 0{ }^{\circ} \mathrm{C}$ の範囲で推移し, 栽培期間を通じて
無処理区の地温が高かった. 1 月 22 日播種も同様に $-0.5 \sim$ $0{ }^{\circ} \mathrm{C}$ の範囲で推移し，栽培期間を通じて無処理区の地温が 高かった (第 3 図). 最低地温は早朝の時間帯となるため茎 葉による地表面被覆の影響は小さいと考えられる。 9 月 21 日播種以外で液状マルチ処理区の地温が無処理区よりも低 

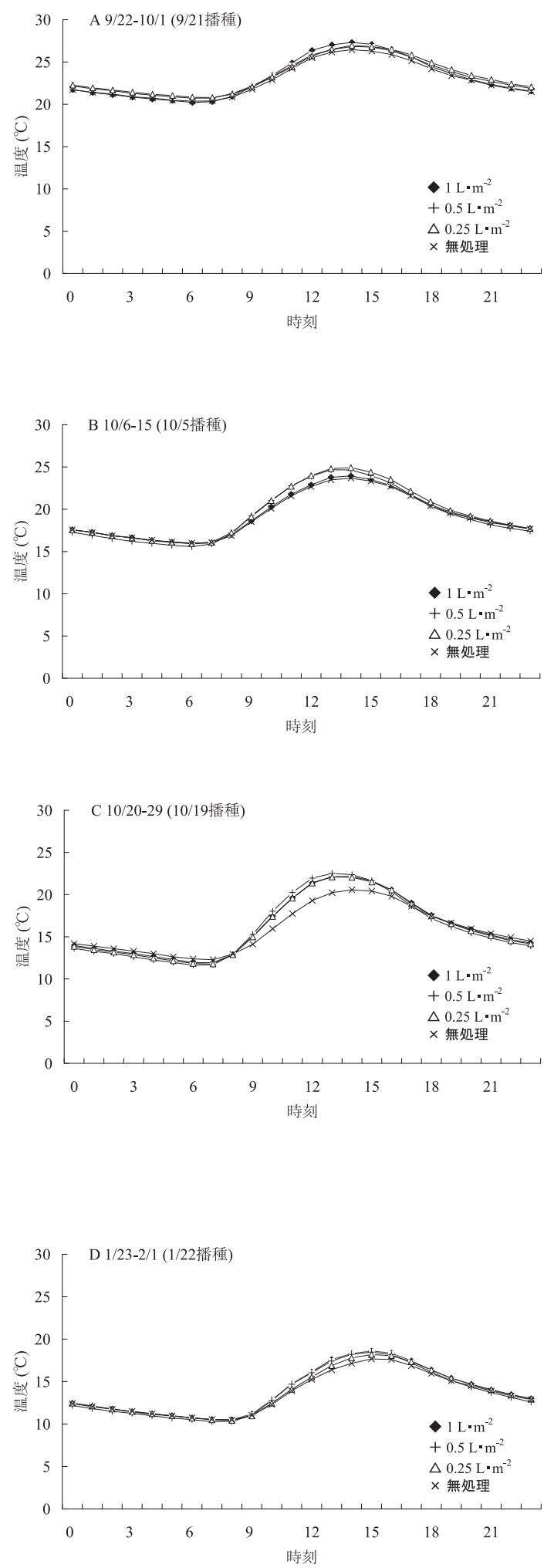

第 4 図 液状マルチ散布量が播種後 10 日間の地中 $5 \mathrm{~cm}$ の平均 地温の日変化に及ぼす影響

下した原因を明らかにするため, 液状マルチ処理区と無処 理区の地温差に影響を与えることが予想されるパラメータ との相関関係を求めたが, 一定の傾向はみられなかった(第
2 表).

播種後 10 日間の平均地温をみると, 9 月 21 日播種では, $1 \mathrm{~L} \cdot \mathrm{m}^{-2}$ 区では夜間は無処理区と核同等に推移し，日中 は $12 \sim 13$ 時にかけて最大 $0.9^{\circ} \mathrm{C}$ 高かった. $0.5 \mathrm{~L} ・ \mathrm{~m}^{-2}$ 区で は終日，0.3 $0.5^{\circ} \mathrm{C}$ 高く推移した。 $0.25 \mathrm{~L} ・ \mathrm{~m}^{-2}$ 区では日中 $0.2 \sim 0.5^{\circ} \mathrm{C}$, 夜間は $0.4 \sim 0.7^{\circ} \mathrm{C}$ 高かった (第 4 図 $\mathrm{A}$ ). 10 月 5 日播種では, $1 \mathrm{~L} ・ \mathrm{~m}^{-2}$ 区は無処理区に対して $-0.1 \sim 0.3^{\circ} \mathrm{C}$ で経過し，日中は無処理区と同等以上に推移した． $0.5 \mathrm{~L} ・$ $\mathrm{m}^{-2}$ 区では日中 $11 \sim 13$ 時にかけて $1.2^{\circ} \mathrm{C}$ 高く, 夜間は $0.3 \sim 0.4^{\circ} \mathrm{C}$ 低かった. $0.25 \mathrm{~L} \cdot \mathrm{m}^{-2}$ 区では $12 \sim 14$ 時にか けて $1.3^{\circ} \mathrm{C}$ 高く, 夜間も無処理区と同等かそれ以上で推移 した（第 4 図 B). 10 月 19 日播種では, $1 \mathrm{~L} ・ \mathrm{~m}^{-2}$ 区は日中, 12 時の $2.1^{\circ} \mathrm{C}$ をピークに無処理区より高く推移したが，夜 間は $0.1 \sim 0.5^{\circ} \mathrm{C}$ 低かった. $0.5 \mathrm{~L} \cdot \mathrm{m}^{-2}$ 区も 12 時の $2.7^{\circ} \mathrm{C}$ を ピークに高く推移したが, 夜間は $0.3 \sim 0.8^{\circ} \mathrm{C}$ 低かった. $0.25 \mathrm{~L} ・ \mathrm{~m}^{-2}$ 区も 12 時の $2.1^{\circ} \mathrm{C}$ をピークに高く推移したが, 夜間は $0.1 \sim 0.6^{\circ} \mathrm{C}$ 低かった（第 4 図 C). 1 月 22 日播種で は $1 \mathrm{~L} ・ \mathrm{~m}^{-2}$ 区は日中, 13 時の $1.2^{\circ} \mathrm{C}$ をピークに無処理区よ り高く, 夜間子同等か, それ以上に推移した。 $0.5 \mathrm{~L} \cdot \mathrm{m}^{-2}$ 区 は日中, 14 時の $1.1^{\circ} \mathrm{C}$ をピークに高く推移したが, 夜間は $0.2 \sim 0.3^{\circ} \mathrm{C}$ 低かった. $0.25 \mathrm{~L} \cdot \mathrm{m}^{-2}$ 区では 13 時の $0.6^{\circ} \mathrm{C}$ ピークに無処理区より高く，夜間も同等か，それ以上に経 過した（第 4 図 D)．播種後 10 日間の毎時積算温度を比較 すると，液状マルチ資材散布量の間に有意な差は認められ なかった (第 3 表)。すなわち, 生育の初期段階で作物によ る地表面被覆の影響が小さい場合, 液状マルチ資材散布に より日中の地温は上昇するが, 逆に夜間は低下寸るため, 結 果的に積算地温は同等であった，夜間の地中から大気への 放熱は，上向き地表伝熱が大部分を占める（林，2003）。黒 色ポリマルチをハウス内で使用した場合，上向き地表伝熱 が抑制されるためハウス内気温は無マルチに比べて低下す る. その原因として，古在ら（1985）はポリマルチフィル ム裏側に付着した水滴によって長波透過率が低下すること が原因であると推察している，これに対して本資材は土壌 表面と一体化し水滴などは発生しないため地表から空気中 への赤外線の放射が水滴により抑制されることはない。す なわち秋冬季の夜間には上向き地表伝熱が増大し，無処理 区に比べて地温の日較差が増大したものと考穴られる。こ のほかに夜間の地温低下の原因として地表面からの水分蒸 発の可能性も考えられるが，低温期ではこの影響は少ない との報告もある（三田村ら，2001）。本実験でも土壌 $\mathrm{pF}$ 值 に処理区間で特に差異は認められなかった（データ略）こ とから無マルチと液状マルチの間で水分蒸発量に大きな差 はないものと考觉られる。根本ら（2007）が無マルチの地 表面温度の日較差に対する各種マルチ資材下温度の日較差 の比（日較差比）を作物栽培していない状態で調査したと ころ，本実験に抢ける液状マルチと同様に無マルチに対し て最高地温が高く, 最低地温が低かった資材は透明マルチ のみであった。 しかしダイコンを栽植した場合，透明マル 
第 3 表 液状マルチ処理がコマツナ播種後 10 日間の毎時積算温度に及ぼす影響

\begin{tabular}{ccccc}
\hline \hline 播種日 & 9 月 21 日 $\left({ }^{\circ} \mathrm{C}\right)$ & 10 月 5 日 $\left({ }^{\circ} \mathrm{C}\right)$ & 10 月 19 日 $\left({ }^{\circ} \mathrm{C}\right)$ & 1 月 22 日 $\left({ }^{\circ} \mathrm{C}\right)$ \\
\hline 無処理 & 5,547 & 4,626 & 3,888 & 3,336 \\
$0.25 \mathrm{~L} \cdot \mathrm{m}^{-2}$ & 5,579 & 4,643 & 3,860 & 3,286 \\
$0.5 \mathrm{~L} \cdot \mathrm{m}^{-2}$ & 5,602 & 4,711 & 3,866 & 3,300 \\
$1 \mathrm{~L} \cdot \mathrm{m}^{-2}$ & 5,485 & 4,605 & $\mathrm{~ns}$ & $\mathrm{~ns}$ \\
\hline $\mathrm{F}$-test & $\mathrm{ns}^{\mathrm{z}}$ & $\mathrm{ns}$ & & $\mathrm{ns}$ \\
\hline
\end{tabular}

z: 1-way ANOVA により有意差なし

チの最低地温は無マルチより高くなった. 本試験で同程度 の気温となる 10 月 19 日播種では, 液状マルチ区の最低地 温は常に無処理区より低かった. 今のところこのよらな特 性を有する資材はほかに見あたらず，液状マルチ特有の性 質と考えられる. 液状マルチの着色に用いられる黒色顔料 の原料は炭素粉末で，その一般的な性質として赤外線を吸 収し，発熱する作用があるが，製品によってもそれらの性 質は大きく異なり，原材料メーカーによる情報開示がなさ れないため伝熱性については不明である。な抏，元木ら （2007）は，トンネル内で本資材を使用することにより，ア スパラガスの萌芽が顕著に早まったことを報告している. これは, 古在ら（1985）が示した黒色ポリマルチフィルム によるハウス内気温の低下とは逆に, 液状マルチ資材によ り夜間の上向き地表伝熱が増加した結果, トンネル内気温 の上昇による可能性が考えられた．また，石井・新堀 (1988) はさまざまな温度下に拈ける収穫直後のカブの呼吸速度を 測定したところ, $1 \sim 10^{\circ} \mathrm{C}, 10 \sim 20^{\circ} \mathrm{C}$ の範囲内では $1^{\circ} \mathrm{C}$ 上 がるごとにそれぞれ約 1\%，1.5\%上昇していた。本実験に おいては地温が呼吸に及ぼす影響を調査していないが，液 状マルチの夜間の地温の低下はコマッナの呼吸を抑制した 可能性が示唆された。 その一方で, 夜間の地表面からの赤 外放射はコマッナ自体の体温を上昇させ，呼吸を高める可 能性も否定できない, 従って, 液状マルチ資材が生育に及 ぼす影響を明らかにするためには, 地温ならびに群落内微 気象について詳細な解析を行ら必要があると考えられる. 今後は散布処理が簡便で, かつ廃棄物を生じない環境保全 型資材としての特性（工藤ら，2007; 中川ら，2004）を生か しつつ, 顔料組成の調整により使用時期や作物の適正に応 じて地温制御能力を具備した資材として改良を重礼ること により軟弱野菜生産への普及の可能性が高まると考えられ る。

\section{摘 要}

黒色の液状マルチ資材が地温ならびにコマッナの生育, 収量に及ぼす影響を明らかにするため，処理量を $1,0.5$, $0.25 \mathrm{~L} \cdot \mathrm{m}^{-2}$ 区および無処理区の 4 水準 3 反復, 播種日を 2007 年 9 月 21 日， 10 月 5 日，10月 20 日抢よび 2008 年 1 月 22 日の 4 水準として組み合わせ, 栽培試験を行った. その結果, 液状マルチ資材は, 散布量に関わらず無処理に 比較して増収することが明らかになった. 地下 $5 \mathrm{~cm}$ の温度 を解析したところ, 液状マルチ散布により最高地温は上昇
するが，9月 21 日播種を除き最低地温は低下した．この現 象はコマッナの生育初期に顕著であったが, 生育に伴って, その差は小さくなった. 播種後 10 日間の毎正時積算地温に 有意な差は認められなかった。地温の日較差の増大はコマ ッナの増収に寄与した可能性が考えられた。

\section{引用文献}

林 真紀夫. 2003. 保温. 五訂施設園芸ハンドブック.p. 116127. （社）日本施設園芸協会. 東京.

石井 勝・新堀二千男. 1988. コカブの呼吸量及び数種内容 成分の変化と外観品質との関係. 園学雑. 57:319-323.

門田寅太郎. 1972. 疏菜の生育に及ぼす土䁃温度の影響. 高知大農紀要. 21: 1-138.

小寺孝治. 2003. マルチ・ベたがけ資材と利用. 五訂施設 園芸ハンドブック.p. 75-84. (社) 日本施設園芸協会. 東京.

古在豊樹・菅 明子・奥矢 毅・渡部一郎. 1985. 敷きわ ら拈よびフィルムマルチが無暖房八ウスの夜間温湿度 環境に打よぼす影響. 農業気象. 40: 393-397.

工藤光夫・中川公一・小倉秀一・池島敏二・鈴木尚俊・斉藤 康一・元木 悟. 2007. 液状塗布型被覆資材（エコ・サ ンコート）の開発とその特性. 園学研. 6別1: 438.

三田村直樹・太田良祐・八島茂夫. 2001. マルチングによ る土壤物理性の制御. 三重大生資農場研報. 12:1-12.

中川公一・金澤貴司．2001．液状マルチング方法及び液状 マルチング資材．特許公開2001-45879.

中川公一・小倉秀一・池島敏二．2004．液状マルチ資材及 びマルチ敷設方法. 特許公開2004-313048.

中島 譲・森田隆史・片岡圭子・札埜高志・河瀬晃四郎. 2003. シードテープと紙マルチの組み合わせによる葉 根菜栽培の試み. 園学研. 2: 293-296.

根本和彦・ポンサアヌティン ティーラサク・鈴木晴雄. 2007. 温度日較差比による各種マルチ資材の温度効果. 香川大農学報. 59: 7-14.

元木 悟・鈴木尚俊・干川学哉・本井 浩・中川公一・ 小倉秀一 - 小林 淳 - 工藤光夫 - 斉藤康一 ・ 臼井冨太. 2007. 液状マルチがアスパラガスの萌芽および収量に 及ぼす影響. 園学研. 6別 1: 437.

富田真佐男・多々木英男・小田雅行・岡田邦彦・佐々木秀和. 1997. マルチ資材散布による夏まきホウレンソウの生 産安定．群馬園試研報。 2: 1-9. 